\title{
Piracy in Somalia: A Challenge to The International Community
}

\author{
Santiago Iglesias Baniela ${ }^{1}$ and Juan Vinagre Ríos ${ }^{2}$ \\ ${ }^{1}$ (Navigation and Earth Sciences Department, A Coruña University, Spain) \\ ${ }^{2}$ (Vessel Surveyor) \\ (E-mail: sbaniela@udc.es)
}

\begin{abstract}
In the paper Piracy at Sea: Somalia an Area of Great Concern (Baniela, 2010), a general up-to-date vision of piracy at sea in Somalia was analysed. As piracy at sea has political, socio-economic, security and humanitarian dimensions, the international community requires a thorough approach that embraces a comprehensive and multi-faceted response of effective counter-measures, both onshore and offshore. So as a follow-up to that paper, the objective of this one is to analyse the impact of the current strategy in the struggle against piracy in Somalia carried out by the international community focused solely at sea and to examine the proposals to find a solution to the problem on land.
\end{abstract}

\section{KEY WORDS

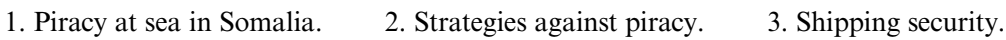

Submitted: 31 January 2012. Accepted: 20 April 2012. First published online: 15 June 2012.

1. INTRODUCTION. The history of international awareness of, and concern with, modern-day piracy dates back to Southeast Asia in the early 1980s. From the middle of the last decade, the problem is especially focussed in the Indian Ocean, and has acquired an international dimension which destabilizes one of the world's most important maritime trade routes (Kraska and Wilson, 2008 [p. 41]). It also destabilizes the world economy and affects the safety and security of crewmen who sail in that area.

The approach to solving piracy in Somalia (See Figure 1) should be both from land and sea; but the current strategy developed by the international community is only focused at sea. Considering that there is consensus among analysts that the best and ultimate solution lies on land, this seaborne focus tackles the symptoms but not the roots of the piracy problem. Accordingly, it is unlikely that pirates will change their risk-to-reward calculation and thus the attacks will continue. Therefore, although no single response will solve the problem and despite the international community's apparent lack of capability or will to face up to the task, there is an urgent need for a land-based approach which tries to implement coherent proposals in support of the sea-based anti-piracy measures. The purpose of this paper is to analyse these questions. 


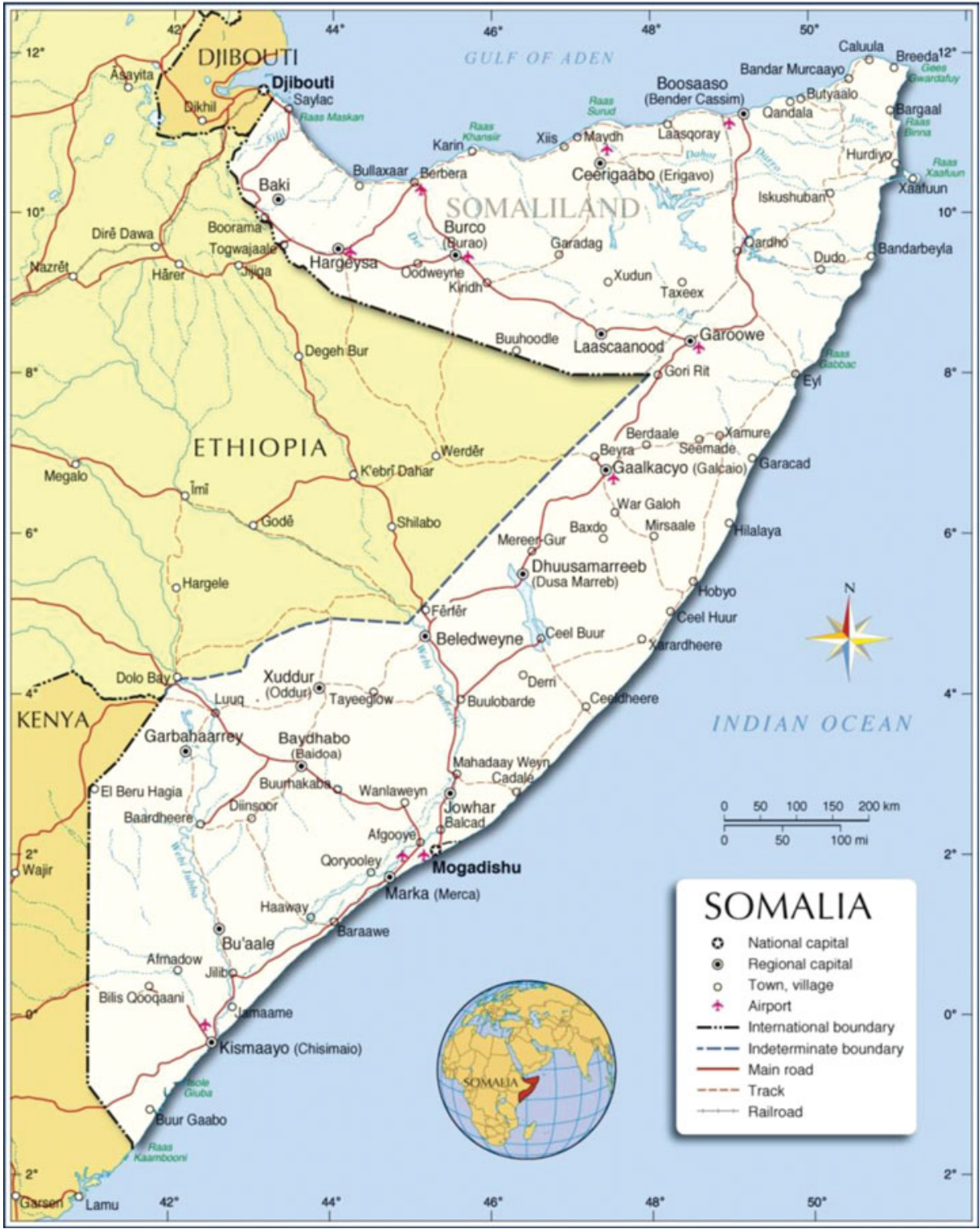

Figure 1. Political map of Somalia and the surrounding countries with international borders. Source: Nations Online Project (http://www.nationsonline.org/oneworld/map/somalia-politicalmap.htm).

2. PIRACY HISTORY BACKGROUND. Piracy has been a cyclical phenomenon throughout history. Traditionally, it starts with attacks on vulnerable ships at a small scale, which at first are more a nuisance than a true threat. However, if steps are not taken to control it and the rewards are enough, piracy starts to prosper; the greater the frequency and intensity of attacks, the more seriously maritime traffic is affected and it is then that the international community responds. Thus, in the last cyclical stage, the piracy threat becomes so relevant that the world maritime powers 
react, organizing with each other to send warships to the area to control it. That is certainly the case with Somali piracy after the United Nations Security Council Resolutions (UNSCRs) throughout 2008. Today, the literature is full of countless books and papers about piracy on the Somali coasts, where we can conclude that this phenomenon has followed the traditional cycle.

It is worth considering whether piracy in the Indian Ocean may be eradicated by means of naval operations which only focus on the issue of securing sea lanes or protecting merchant shipping. Unfortunately, if we analyse this phenomenon in its historical context (Wombwell, 2010), it clearly shows that piracy at sea has never been completely eradicated only by using warships stationed on the spot to fight it. The reason, as has been so often repeated lately (Isanga, 2010 [pp. 1311-1312]; Murphy, 2009; Ong-Webb, 2007[p. 90]), is that although the problem occurs at sea, it is based on land; and as long as it is not seen from this viewpoint ${ }^{1}$, it will never be eradicated. In this sense Wombwell (2010 [p. 13]) describes the USA President James Monroe's proposal during the second phase of the Caribbean Piracy in the $19^{\text {th }}$ century that seems still valid nowadays when he suggested that some forceful actions against Spanish people should be carried out to end Spanish support to piracy in Cuba and Puerto Rico in late 1824.

3. THE FAILED STATE CONDITION OF SOMALIA. In international law, the sovereignty principle is linked to the notion of statehood as a source of its basic authority and it is expressed in the right of each state to solve national matters without interferences of any other state.

Not carrying out the nation's duties supposes a threat to the structure of international relations caused by the misuse of power by coordinated institutions and the lack of a governmental authority which can offer security to its residents. This is different to a consolidated state, where a regime of law and order exists that can serve as the foundation for the international system.

In customary international law, some of the main characteristics that identify a state $^{2}$ should in any case include a permanent population, a defined territory and a government capable of maintaining effective control over its territory and conducting international relations with other states or gaining international recognition.

The contemporary assessment of countries such as Somalia, Chad or Sudan (Failed States Index, 2011) $)^{3}$ causes a great concern about the adaptation of this traditional definition (Sepúlveda, 2009); it has given rise to the concept of a 'failed state'. This term itself is fairly recent and was first used by Helman and Ratner (1993 [p. 3]), which has specific characteristics from a geographical (mainly connected to internal and endogenous problems), political (they face internal law and order collapse) and functional view (they lack bodies able to represent them at an international level

\footnotetext{
${ }^{1}$ If we want to eradicate piracy, it becomes necessary to stabilize the country and to provide the citizens an alternative means of life which enables the elimination of support for piracy on land; otherwise, piracy re-emerges again when the conditions become favorable, although it may be temporarily suppressed.

2 Following Art. 1 of the 1933 Montevideo Convention on the Rights and Duties of States.

3 An annual ranking prepared by the Fund for Peace of the world's most vulnerable countries where Somalia has held the No. 1 spot for four years in a row, indicating the depth of the crisis in the international community's longest-running failure.
} 
and they also suffer from the ability to accept the external influence) (Thürer, 1999 [p. 734]).

Assuming the previous general considerations, it is not a surprise that Somalia is widely perceived as a failed state (Cronjé, 2010; Silva, 2010) without a stable government since 1991. It lacks a functional economy, with various powerful factions (warlords and militant Islamic groups) possessing little, if any, national allegiance. They currently fight for the control of the country, where pirates are able to operate with impunity from Somali coastal towns or even camps; this situation is the root of the revival of piracy acts in this area from the middle of the last decade (Riggs, 2009 [p. 2]).

4. THE NEED FOR A LAND-BASED APPROACH. There is a requirement in the fight to eradicate piracy in an area where the international community is faced with 'propitious geography' 4 in favour of the pirates who are able to use it to their advantage. However, there is another necessary land-based factor which encourages piracy to prosper; Somalia is a country wracked with political turmoil. Somalia has not had a viable government since Mohamed Said Bare was ousted from power in 1991; pirates take advantage of this instability and uncertainty which usually brings poverty to the population as a consequence. There are few alternative economic opportunities onshore and this means potential pirates are ready to embark on criminal activities as a means of survival (Kraska and Wilson, 2009 [p. 44]). Consequently, we find that pirate sanctuaries (Baniela, 2010 [p. 206]), essential to maintain their criminal activity, have arisen as piracy becomes an acceptable activity ${ }^{5}$ among the population involved. Thus, in some communities, piracy has even become an acceptable 'profession' (Riggs, 2009 [p. 4]). Although Somalia does not have a cultural history of piracy, it has become acceptable because the dire conditions in the country have led to chronic poverty, starvation and lawlessness. This has usually left Somalis with little alternative to such an extent that, according to Middleton (2011 [p. 23]), piracy is now likely to be the second largest generator of money in Somalia, only surpassed by remittances from Somalia's large and dispersed diaspora. On the other hand, pirates are seen by local Somalis to be filling the void left by the absence of a government to protect Somalia's offshore interests, after claiming that they have assumed those duties.

More widely, Murphy (2008 [pp. 161-166]) analyses six factors (besides geography) that enable piracy to occur, which may be considered a consequence of the condition of a failed state in Somalia.

\section{PROPOSALS INVOLVING SOMALIA ADOPTING} APPROACHES TO FACE UP TO THE PROBLEM ON LAND. The best solution to efficiently cut out piracy is to get a stable government in Somalia that

\footnotetext{
${ }^{4}$ In the case of Somalia (although it has not got thousands of islands where pirates may hide and wait to carry out small sudden attacks on their victims, as in Indonesia), firstly Somalia has about 1,880 miles of coastline in the Gulf of Aden and the Indian Ocean; secondly, Somalia is close to the Gulf of Aden; and finally, there are limited options if a shipping company chooses to avoid the Gulf of Aden as the only alternative requires ships to go round the Cape of Good Hope (South Africa), adding time, fuel and crew costs.

${ }^{5}$ Pirates are offered shelter in many sanctuaries all along the Somali coast as the ransom money available is a valuable help to the coastal villages, where normal trading is almost non-existent.
} 
may control its coasts and avoid the pirates' sanctuary ports, together with improved prospects for economic development and security (Silva, 2010 [p. 555]). The study and analysis of the most appropriate state model which may solve the Somali situation (centralized or decentralized) is very controversial, given the Somali idiosyncrasy, the history and background of the country, making different proposals arise. Thus, as the strategy of establishing a central government model which works in Somalia has been proved ineffective for dealing with instability and has repeatedly failed because none has been able to establish its rule over a significant portion of the country; the Transitional Federal Government (TFG) ${ }^{6}$ is the $14^{\text {th }}$ such interim government structure since 1991 and although internationally recognized, it proved to be a weak institution hindered by a lack of legitimacy among the Somali population.

Some authors propose recognizing the failure of imposing a centralized state authority, arguing that the experience indicates this strategy is not viable. Instead, they propose moving toward support a 'grassroots model' of identifying, establishing, building and improving existing legitimate authorities (including civil society and traditional clan authorities), provided that they do not support or have links with terrorism, piracy, or Islamic extremism. Although applying this strategy will take time and face many difficulties, they consider such an approach more likely to lead to success in the long run (McNeill and Schaefer, 2009; Schaefer, 2009; Schermerhorn, 2011). Also, as the current anti-piracy efforts are not effective in preventing and deterring Somali pirates, Bair (2009) proposes alternative solutions; instilling distrust and suspicion within the groups and undermining the alliances between the pirate groups and their support structures have been used to disrupt criminal organizations in the past and may be effective in combating Somali piracy. Some scholars and analysts show such a discouraging vision of the problem that they doubt the real possibility of the stabilization of the country any time soon and, even more drastically, they state that "Given this Somali view of the state, it is unsurprising that the entrance of the TFG into the country has increased violence...we find that rather than chaos, statelessness seems to have generally improved living conditions in Somalia" (Powell et al., 2008 [p. 669]). In the same sense “... even if Somalia's ability to improve is constrained by statelessness, Somali development would still be better served under anarchy than it would be under government..." (Leeson, 2007 [p. 707]).

Lately, scholars have considered the possibility of issuing 'Letters of Marque' to 'private actors' as an anti-piracy strategy. This has given a contemporary understanding of those licenses and it has been considered a viable legal option to be employed by the USA (Richard, 2010; Schwartz, 2010), but is obviously not the same as was issued to privateers in the 'Golden Age of Piracy' from the 1650s to the 1730s, (as privateering was abolished by the Declaration of Paris in 1856). That possibility was contemplated in a wider sense by Hutchins (2011) developing the concept of how such a legal framework could be structured under both domestic and international regimes, and proposing the establishment of an international system of issuing Letters of Marque and how it might effectively deter pirates while adequately compensating and controlling privateers.

6 The expiration of their transitional situation, that took place in August 2011, was extended for another year at a UN sponsored conference in Kampala (Uganda) on 9 June 2011, deferring elections until 20 August 2012. 
Atallah (2011) emphasized that piracy must be tackled head-on; he assumed that piracy could not be stopped solely at sea and that development of a comprehensive land-based approach is essential. Consequently, he points out that the primary method of combating Somali piracy should be to disrupt its economic system by pressuring and disrupting the cashflow through the key players that finance piracy. But at the same time, they need be offered sufficient economic incentives to replace the lure of piracy. This strategy, as the author himself recognises, has to face up to the current limited accessible research that identifies those key players and thus reveals a gaping hole in this approach.

A strategy to address piracy at regional level was implemented in Southeast Asian countries in the middle of the last decade. Due to the effectiveness of those measures in preventing and deterring piracy operations (although, according to ICC-IMB Report (2006-2010) this threat seems to have resurfaced once again in this region ${ }^{7}$ ) that contributed to the substantial drop in piracy attacks in the region and was largely attributable to coordinated patrols by the coastal states ${ }^{8}$. There are proposals to adopt a similar strategy in the struggle against Somali piracy, but its implementation is charged with more difficulties than in Southeast Asian countries.

On the one hand, besides the establishment of the Rule of Law ashore in coastal areas which prevented the pirates from operating successfully, the patrols in the Malacca Strait were performed by the three littoral states involved, which allowed them to combat piracy at its source, and this strategy made it possible to exert control over the landward side of the littoral. Meanwhile, the patrols in the Horn of Africa have been performed by various coalitions of warships from the international community. Therefore, maritime enforcement only affects the seaward side of the littoral. But unfortunately, the total number of attacks (attempted and actual) has gone up (ICC-IMB Reports 2006-2010) ${ }^{9}$, although the rate of successful ones at actually seizing control of vessels has decreased. According to Middleton (2011 [p. 24]), the increase in overall attacks is ascribable to several factors: the increased number of pirates, the improvement in their tactics and the continuous rise in the ransoms paid for the release of ships and crew.

This increase in piracy is exacerbated because many of the nations that signed the Djibouti Code of Conduct have political and economic problems, which limit their abilities to face some of the most basic causal factors of the piracy phenomenon (Davis, 2009 [pp. 68-69]; Riggs, 2009 [pp. 58-59]).

Due to insufficient evidence in their prosecutorial regime, the states often have no choice but to release the suspected pirates when they come to trial and in order to tackle this shortcoming, Kontorovich (2010; 2011 [pp. 100-103]) proposes the

\footnotetext{
770 total (actual and attempted) incidents against 45 in 2009, 55 in 2008 and 69 in 2007.

${ }^{8}$ Particularly the Malacca Strait Sea Patrols (MALASINDO) in the Malacca Strait among Malaysia, Singapore and Indonesia in 2004, the Eyes in the Sky (EIS) plan to increase the coverage and response times to surface forces in 2005 and the Regional Cooperation Agreement on Combating Piracy and Armed Robbery against Ships in Asia (ReCAAP) in 2006.

${ }^{9}$ This assertion is based on the numbers provided in this report (2006: 20 attempted and actual attacks, 6 actual successful attacks; 2007: 44 attempted and actual attacks, 12 actual successful attacks; 2008 : 111 attempted and actual attacks, 42 actual successful attacks; 2009: 217 attempted and actual attacks, 47 actual successful attacks; 2010: 219 attempted and actual attacks, 49 actual successful attacks). This suggests that, as there is a low probability that a warship would be close enough to hinder an attack, the lower rate actual/ successful attacks can be due to the counter-measures in place carried out by the merchant vessel's crew as the ships know this is a high-risk area.
} 
promulgation known as 'equipment articles'. This could help prosecute captured pirates, creating a judicial presumption of blame on piracy charges for crews on-board their civilian vessels if they are equipped with certain specified equipment, unnecessary for their functions as fishermen, but that the pirates customarily use to perpetrate their crimes (mainly outboard motors above a determined horsepower, boarding ladders, grappling hooks, arms such as RPGs, insufficient provisions for the zone of high seas where they are, that can suggest they are operating from a mother ship). The author quotes legal precedents stating that similar rules were in force in the past, permitting the prosecution of the transatlantic slave trade in the $19^{\text {th }}$ century, and are now in place in the 2005 Protocol to the 1988 Convention for the Suppression of Unlawful Acts against the Safety of Maritime Navigation (SUA Convention). He also analyses different options with their advantages and disadvantages of implementation in the fight against Somali piracy. With different wording but the same end, Roach (2010) refers to piracy paraphernalia subject to confiscation, suggesting that their possession should evidence a piracy attempt.

As we have seen up to now, although there are proposals aimed to stop piracy by stabilising and reconstructing Somalia; this option seems improbable in the near future as, considering the historical background (Cronjé, 2010; Møller, 2009), it is very unlikely that the country can find a solution by itself in the short or medium term due to the generalized misgovernment situation. Because it is also doubtful that the international community has the capability or will to carry out the task on land, where the root causes of piracy are located, international action seems limited to keeping a maritime task force in the region.

A probable factor behind the lack of will of the international community to adopt a determined land-based strategy is the failure of the so-called 'humanitarian interventions' in the 1990s that have discredited the motives of the western countries for the country's pacification, which has made Somali people reluctant to involve themselves in nation-building efforts since then. During this decade, both violence and a severe drought plunged the country into widespread poverty, which led the USA and the UN to a singularly ineffective, even counter-productive, international humanitarian and military intervention from 1993 to 1995. This intervention failed to restore peace and withdrew from Somalia without restoring a central government, although thousands of lives were saved through food aid. The last peacekeepers left the country in 1995, leaving it in an even worse state than when they had arrived; little progress has been made over the last 16 years. This fact has not been forgotten by Somali people, most of whom now have a mistrust of both the UN and the USA. In fact, they united against the foreign presence and eventually forced the USA to withdraw after the incident in 1993 known as "Black Hawk Down" (Bordas, 2009; Møller, 2009 [p. 12]).

\section{THE DIFFICULTIES OF FINDING A MEDIUM-TERM} SOLUTION TO COASTAL STATES. Anti-piracy responses at national level by Somalia and its neighbours (Kenya, Yemen and Tanzania) have had little success, primarily because of the lack of resources and support from within their countries and the international community.

Bilateral cooperation between regional governments has mainly focused on establishing legal and jurisdictional mechanisms for the transfer, detention and trial 
of suspected pirates and due to the lack of cooperation, resources and political instability within the region, the bilateral response has been largely ineffective and insufficient in the struggle against piracy there, although with signs of progress.

Regional cooperation based on factors such as social and cultural balance, parallel attitudes and objectives, mutual political and/or economic dependence, and a geographical proximity, among others carry greater global legitimacy than global arrangements do. This is probably because they are less likely to be seen as impositions and should play an overriding role to provide support to nations with piracy problems.

In this sense, nowadays the most important instrument is the IMO sponsored Djibuti Code of Conduct adopted in January 2009, that was inspired in the Regional Cooperation Agreement on Combating Piracy and Armed Robbery against Ships in Asia (ReCAAP), adopted in 2004. This agreement marks the first major regional effort to cooperate in the repression of piracy off the coast of Somalia and in the Gulf of Aden. The effort carried out by regional governments to cooperate in piracy and robbery matters at sea are promising (the creation of mechanisms to promote greater cooperation between the Somali TFG and the regional governments of Somaliland and Puntland starting from January 2010 should be highlighted). However, these efforts are still insufficient because many of the nations that signed the agreement (17 regional governments) have political and economic problems that limit their abilities to address some of the most basic causal factors of piracy. Furthermore, the Code encourages governments, but does not require them to act, which provides little incentive to cooperate and in the end the results depend on whether there is enough capital to ensure that the agreement is well implemented. Even if these provisions establish an improvement on the UNCLOS framework, as a regional agreement, it does not create an international body against piracy, it is a non-binding document and the crime must be committed on the high seas (Bento, 2011 [p. 427]; Riggs, 2009 [pp. 58-59]).

7. THE CURRENT SEA-APPROACH STRATEGY. The current strategy of stemming Somali piracy has been unsuccessful till now because this action only serves to treat the symptoms of a problem rooted on land. Murphy (2009 [p. 3]) describes the response as "The least efficient and cost-effective form of piracy suppression" emphasising that "the belief that piracy can be suppressed solely at sea is largely illusory" (Murphy, 2011 [p. 36]). The current sea-based strategy seems not to deter more desperate young Somalis eager for the possibility of acquiring relatively substantial wealth. So, these approaches to the solution of the problem are ineffective and unsustainable because supplying such a large naval force is prohibitively expensive and disproportionate in relation to the monetary costs associated with piracy in the region. Even with the unprecedented maritime enforcement regime, navy ships have forced pirates (with the help of mother ships) to shift their operations to areas which they know are not being patrolled (Baniela, 2010 [p. 205]). Currently, the coalitions of warships attempt to maintain eight warships on station at any time and although 40 warships may be deployed to the area, there are seldom more than 12 actually on station for counter-piracy operations at any time, but "... it would take more than sixty warships to provide an effective presence over the length of a single, narrow transit corridor..." (Kraska, 2009 [pp. 149-150]). Such naval forces cannot 
effectively patrol an area of 2.5 million square miles in the Indian Ocean (Hutchins, 2011 [p. 828]).

As Bento (2011 [p. 412]) recognises, security concerns in Somalia expose land-based operations to unquantifiable security risks. This makes any land-based intervention unlikely, even under military protection, and has limited the international response to a sea-based strategy which aims to diminish the attacks to an acceptable level without completely eliminating them or solving the root causes which are the origin of the problem.

It is for this reason that in this sea-based strategy, with the impossibility of naval forces providing complete protection to shipping, self-defence strategies become important. Given the current situation, strict adherence by ships to the Best Management Practices (BMP4, 2011) and the use of Privately Contracted Armed Security Personnel (PCASP) on-board ships become more relevant; they should not be adopted as an alternative but as complementary to BMP4.

To follow the practical advice contained in BMP4 is of overriding importance, especially when ships transit high-risk areas as defined in BMP4. These procedures have been recognised and encouraged by the deployed naval forces in order to enable ships to avoid, deter or delay piracy attacks.

Regarding PCASP, it is an extraordinary controversial matter with experts, analysts, countries and international institutions in disagreement, either for or against it (Baniela, 2010 [pp. 202-204]). Nevertheless, last year was a turning point as relevant institutions, such as International Maritime Bureau (IMB) and International Maritime Organization (IMO), and many countries have tempered their positions against it by adopting a neutral attitude. The IMO through its Maritime Safety Committee (MSC) enacted three Circulars in September 2011 in order to give interim guidance and recommendations on the use of PCASP to shipowners, ship operators and shipmasters (IMO, 2011a), to flag states (IMO, 2011b), and to port and coastal states (IMO, 2011c). This seems an important step in order to clarify their potential use by the shipowners and to foster the necessary development of a complete regulation in every sense.

Therefore, having ruled out the short-term objective of eradicating piracy, what is really considered is to neutralize the pirates' actions or to minimize their consequences. However, planning the fight against piracy by the deployment of aeronaval units focused on capturing and prosecuting seagoing pirates, has to consider the legal, jurisdictional and practical limitations that international law presents, besides the intrinsic limitations previously analysed. Many legal, jurisdictional and practical limitations are derived not from the international law in itself, but from its implementation on the part of the national legislation of the states (Guilfoyle, 2010 [p. 142]) which determine the operational aspects of the missions ${ }^{10}$. These shortcomings minimize the risk pirates take each time they attempt to hijack a ship and, until those risks outweigh the reward, piracy will continue to be difficult to stop. Further details about these legal aspects are contained in the Appendix to this paper entitled: 'International legal framework about piracy regarding Somalia'.

\footnotetext{
10 Since naval force operations are primarily using law enforcement mechanisms, they are forced to rely upon international law and national laws to combat piracy.
} 
8. CONCLUSIONS. The boom that piracy has undergone in Somalia since about the middle of the last decade has threatened one of the world's main maritime trade routes and called for an international community response. That response was an unprecedented naval force deployment to patrol the zone as a response to UNSCRs calls since 2008, aimed at countering piracy attacks. Despite the best efforts of the naval forces, this task has become impossible to accomplish because of the current expanse of the area to patrol, a factor that complicates the naval strategy per se.

An analysis of the piracy phenomenon throughout history reveals that to eradicate piracy it has always been necessary to carry out a determined action on land because, as has been repeated so many times lately, piracy is manifested at sea but it has its roots on land. The main necessary factors for piracy to flourish are having 'propitious geography', political instability and pirate sanctuaries; as the geography of the area cannot be changed, the anti-piracy focus should be centred on the two remaining enabling factors, both of which are land-based. In Somalia these two factors are directly correlated with their well-earned reputation as a failed state.

Regarding political instability, due to the absence of economic interests on the zone combined with the failure of humanitarian interventions that finished with the retreat of the UN in 1995, it is doubtful that, in the short and medium term, the international community has the capability or will to address it, being reluctant to engage in this task.

Regarding pirate sanctuaries, there are no known military plans and an apparent lack of appetite to unleash attacks on land against them, even by nations such as the USA that supported the wording of the UNSCR 1851/2008 that opens this possibility.

The solution in Somalia goes through restoring peace and order and, as it is one of the poorest countries, establishing alternate income-earning activities for the Somali population to the lucrative 'business' of piracy, achieved through ransom payments. The question is how to address the problem because it is so intricate that there is no single response and a need to address the phenomenon by a comprehensive approach is necessary. The preferred centralised-state option that the international community has supported from the beginning (for 20 years now, when Somalia became a failed state) has repeatedly failed. This fact reveals that it is probably time to try other alternatives. Thus, the 'grassroot models' as opposed to the centralised-state strategy and the efforts towards the identification of key players that finance piracy and the pressuring and disrupting of their cashflows, are land-based proposals that could be effective. Regarding the prosecutorial regime, to facilitate evidentiary items, known as 'equipment articles', seems a worthwhile proposal to attempt their implementation.

To sum up, if the international community wants to eradicate piracy in Somalia, it must implement land-based counter-measures. Meanwhile, as naval power is necessary but not sufficient, the consequence of the current strategy focused solely at sea means that, unfortunately, it will not eliminate piracy in Somalia. The pirate's riskto-reward calculation hardly changes and the piracy problem goes on, seeming endlessly, although tempered by ship security self-defence strategies (ie., strict adherence to BMP4 and the use of PCASP mainly after the interim guidance promulgated by IMO MSC Circulars and their desirable development by all parts concerned). That is why a land approach is essential. 


\section{APPENDIX. INTERNATIONAL LEGAL FRAMEWORK ABOUT PIRACY REGARDING SOMALIA.}

In the struggle against piracy in Somalia, the present legal protection provided to shipping by international law is set out on the three following rules of application:

- Arts. 100 to 107 and 110 of the 1982 United Nations Convention on the Law of the Sea (UNCLOS), incorporated almost literally without amendment from Arts. 14 to 22 of the 1958 High Seas Convention (HSC).

- The 1988 SUA Convention, as amended by the 9 May 2005 Protocol, which regulates, among state parties, unlawful acts against maritime safety.

- The UNSCRs regarding Somalia.

\section{A1. THE UNCLOS.}

A1.1 Definition of Piracy. Art. 101 of UNCLOS defines piracy under international law and, for the purposes of this appendix, the key elements an act must satisfy to be considered piracy are all contained within subparagraph (a) and emphasized in bold as follows: "any illegal acts of violence or detention, or any act of depredation, committed for private ends by the crew or the passengers of a private ship or a private aircraft, and directed ... on the high seas, against another ship or aircraft, or against persons or property on board such ship or aircraft".

A brief examination of these elements will reveal the gaps and inherent limitations concerned with modern-day piracy in the existing UNCLOS definition.

- "any illegal acts of violence or detention, or any act of depredation"

Regarding this element, acts of attempted piracy, acts preparatory to piracy and other violent acts indirectly linked to piracy are not included in the definition, falling outside the scope of Art. 101. This constitutes a problem because warships can only capture pirates "in the act".

- "for private ends"

Neither the HSC nor the UNCLOS give a definition of what "private ends" means. Therefore, there are grey areas arising from the questions as to what the purpose was; if the motive of this requirement must be exclusive or if it can be a mixture of privatepublic ends and when the public and the private starts and finishes if the coexistence of both is not possible.

As most scholars point out, the "private ends" condition excludes acts directed at ships or their crew from the definition of piracy that are politically motivated, which nowadays means that this proviso excludes terrorist acts that are politically motivated. It also excludes acts carried out by warships (or other recognized government vessels) although, according to Art. 102, such ships can become pirate ships if seized unlawfully (using a warship by a mutinied crew) and then used to perpetrate piratical acts.

This element of the piracy crime comes from the 1932 Harvard Draft Convention on piracy successively incorporated into the definition of piracy by the HSC and the UNCLOS. The process of incorporating a perpetrator's motive into the definition 
of a crime is not usual. However, when the piracy definition began to emerge internationally, this measure was necessary at international law at the time and appears to arise from the distinction between piracy and privateering (state-sponsored piracy under the license of a letter of marque) of the $16^{\text {th }}$ and $17^{\text {th }}$ centuries.

According to recent statistics, modern-day piracy is an endemic problem, specially nowadays in the Gulf of Aden and off Somalia's east coast. This suggests that the premise considering it a phenomenon of the past is no longer valid - the HSC and UNCLOS conventions were adopted without any thought about a piracy resurgence on the high seas. So, in the absence of any privateering on the high seas, the old "private ends" element of the definition is now obviously outdated.

- "on the high seas"

The piracy definition requires that a violent act must be committed on the high seas. This geographical restriction to high seas seems the most significant shortcoming because it not only limits the offence to the high seas but also enforces power to finish with it.

Regarding piracy, this area should be considered including the Exclusive Economic Zone (EEZ) by operation of Art. 58.2 though prima facie Art. 86 excludes EEZ from the provisions applied to the high seas regime.

At the end of the $18^{\text {th }}$ century, when the customary international law started to materialize regarding piracy, the territorial sea of a state was stretched to about three nautical miles from shore; thus, high seas were all the waters beyond the territorial sea so determined.

At that time, it was established the presumption that the coastal state inside its jurisdiction, including the three nautical miles from the territorial sea, had legislation applicable to offences committed there and was able to enforce those laws. So the international community need not consider how to face the piracy acts taking place anywhere, but not on the high seas, considering that in such cases, it was more appropriate to let the coastal states face the piracy problems in the territorial sea under their control.

In light of the aforementioned, we could assume that the original justification related to limiting the piracy crime to piracy acts taking place on the high seas is not valid nowadays as it cannot be generally assumed that a state will carry out its jurisdiction regarding maritime crimes within its territorial sea. Consequently, the international community should review the suitability of the "high seas requirement" considered in the piracy definition today.

\section{- "against another ship"}

Art. 101 of UNCLOS sets up the "two-ship requirement" stating that the act has to be committed by one ship (the attacking ship) against another (the victim ship) to be considered piracy. The attacking ship must be a private ship (a non-government ship) while it is irrelevant if the victim ship is private or not.

The exception of this general rule is stated in Art. 102 that treats the mutinying crews of state-owned ships as pirates in Art. 101. In this case, UNCLOS establishes a legal fiction considering a government ship as a private ship and therefore subject to the international piracy law. 
The fact of considering the two-ship requirement in the definition lies in the thought that the acts committed aboard only one ship affected the flag state of the ship where they took place so they should not be strictly subject to the international law. Nevertheless, this presents no problem in Somalia as the modus operandi involves the presence of ships, where pirates attack their targets from small boats, usually very fast skiffs, coming from bases on the mainland or from mother ships at sea.

A1.1 Action Against Pirates. Regarding action against pirates, the main provision is Art. 105 that confers a common police or enforcement jurisdiction on any state on the high seas to seize a pirate ship (according to Art. 107 only warships may carry out seizure on account of piracy), arrest the persons and seize the property on-board, and a common judicial jurisdiction to prosecute it in its own court system and punish the offenders. However, the universal jurisdiction over pirates is limited to the high seas, as no nation has the right to enter the territorial waters of a state. Only the state has exclusive jurisdiction to apprehend and the capturing nation may then prosecute pirates in their domestic courts but may not transfer seized pirates to a third country for prosecution.

To sum up, the universal jurisdiction conferred by the UNCLOS regarding piracy has two shortcomings: the geographical limitation, as the power of states to pursue pirates ceases to exist outside the high seas; and the judicial limitation, as the opportunity to prosecute pirates arises only in cases where the capturing state is also willing to prosecute; therefore other states are not entitled to prosecute them.

The problem becomes even worse because UNCLOS does not require states to enact domestic anti-piracy laws according to the convention provisions, as it is based on the assumption that states have adequate domestic legislation to prosecute piracy acts. This causes additional impediments in the piracy struggle as although the international law makes capture outside a state jurisdiction possible, it is the national laws of the capturing state that determine how to punish pirates, not the international law. Although the UNCLOS confers states universal jurisdiction to prosecute pirates on the high seas, as they are under no duty, few states actually do it. Some of them have usually enacted national laws for the prosecution of pirates who have specifically committed offences against either their nationals or flag vessels; the promulgation of these too restricted laws is possible as states have no international obligation to include national offences in their laws for prosecuting pirates who have perpetrated acts considered piracy under international law. As a result, it has led to remarkable failures and, in this respect, the scarcity of piracy cases actually brought in national courts stands out; a fact that exhibits the limitation of international law as a response to modern-piracy.

Another limitation of enforcement jurisdiction comes from Art. 111 that authorizes the hot pursuit of a foreign ship by a coastal state warship provided that there is "good reason to believe that the ship has violated the laws and regulations of that State". The pursuit must begin either within their internal waters, the territorial sea or the contiguous zone and can continue outside the jurisdiction of any state only if it is uninterrupted and must cease when the ship pursued enters the territorial sea of "its own State or of a third State".

As a policy power, the right to approach and visit is contained in Art. 110 that lets a warship send an officer-led party to board a private ship when there are reasonable grounds that it is under piracy suspicion in order to investigate and corroborate it. The problem here is that, up to now, there is not a conclusive jurisdictional interpretation 
of what reasonable grounds constitutes and therefore, the concept can differ depending on the national court jurisdictionally competent. Hence the need to fill this void by establishing what reasonable grounds means once and for all in this context, specially taking into account the wording of this provision in point 3 if "the suspicions prove to be unfounded" or Art. 106 if the suspicious ship is seized without legal justification “... without adequate grounds..." respectively.

Regarding cooperation among states in the eradication of piracy, Art. 100 imposes a legal duty (according to the wording "shall") upon states to cooperate although it offers no particulars on the nature of such cooperation. However, as piracy can only take place on the high seas or EEZ from a legal standpoint, this general duty ends as soon as pirates go into a state's territorial sea. Furthermore, under this provision, UNCLOS stipulates no procedure for punishing the non-fulfilment of a state's responsibilities in the repression of piracy.

A2. THE SUA CONVENTION. The SUA Convention was adopted after the 1985 Achille Lauro incident in response to terrorist attacks against shipping. It does not specifically outlaw piracy (nowhere in their provisions are the words "piracy" or "terrorism" cited); it rather attempts to punish forms of maritime violence not included in the UNCLOS definition, giving the impression of being better adapted to the modern-day piracy phenomenon. Thus, Art. 3 lists particular acts as ship seizure and violence by those on-board that could result in physical injury or damage to the ship or its cargo. This would likely endanger the safe navigation of the vessel, being considered maritime criminal offences in such cases. Therefore, although the drafters did not expect to extend the definition of piracy with prejudicial acts to maritime safety, the SUA Convention may have some intrinsic advantage in the struggle against piracy.

From the list of acts the SUA Convention enunciates as criminal offences, it can be inferred that it tries to remove the limitations UNCLOS states on the key elements embraced in the piracy definition, particularly:

- It does not have the "private ends" requirement; so acts of terrorism politically motivated, and not simply private aims, would fall within the SUA Convention framework;

- It is also applied to attacks against any ship navigating to, through or from the territorial seas, not therefore applying the UNCLOS "high-seas requirement", authorizing states to pursue and capture maritime offenders not only on the high seas, but whenever the victim vessel is in some form of international transit and lastly;

- It no longer requires the "two-ship requirement"; so if hijackers board the ship when it is moored in harbour and overcome its crew and passengers at a later point in time, this would fall within the SUA Convention framework.

The SUA Convention also requires state parties to extradite or prosecute the suspected offenders of maritime violence. If the capturing state cannot take the necessary measures to establish jurisdiction, SUA requires the extradition of the alleged offender to a state that has successfully established it. However, dependency on this Convention is doubtful because the compulsory extradite or prosecute 
requirement deters states most affected by piracy where pirate attacks typically occur, such as Somalia, Indonesia or Malaysia, from ratifying it.

Although the SUA Convention attempts to overcome limitations of the restrictive elements of the UNCLOS definition of piracy, it has not been so widely ratified. Consequently, while UNCLOS is considered a customary international law legally binding on all nations, the SUA Convention is not; therefore, it is only attached to those member states that have ratified it. So, although the SUA Convention may theoretically be regarded as an alluring alternative for piracy-fighting states, its realistic scope turns out to be restricted because of the absence of universal acceptance and ratification.

All this is not applicable to the intra-state coastal traffic movements (it hardly accounts for much in Somalia, unlike Southeast Asia) and if violence on-board is not enough to endanger maritime safety. However, the main loophole attributed to the SUA Convention is the lack of police or enforcement jurisdiction over ships whose persons are suspected of being involved in acts considered offences as defined in the SUA Convention under Art. 3. As in the case of international rules regarding piracy, such a preventive power would allow jurisdictional competent states to board, search, seize and arrest ships and offenders involved in actual or attempted acts that this Convention criminalizes.

When the SUA Convention is envisaged as a weapon in the struggle against modern-day piracy, an additional problem arises as the acts criminalized usually take place in rather poor states like Somalia. Therefore they are unwilling or incapable of allocating the necessary resources to proactively patrol their littoral to capture the alleged offenders.

While at first the SUA seemed an encouraging solution, in practice it has been an inefficient legal tool for taking measures regarding piracy so far, as this Convention has only been used once. Thus, whatever the potential merits it can have as a tool in the fight against piracy, the states seem not to be using it.

A3. THE UNSCRS REGARDING SOMALIA. The UN is entitled to override assertions of the sovereignty principle whenever it acts in the interest of international peace and security. The recent rise in Somali piracy and their well-earned reputation as a failed state highlighted the shortcomings to the provisions of the existing international law and the inability and/or lack of political will of many states to apply them. This fact led the Security Council (SC) to issue a string of ad hoc Resolutions (UNSCRs) since 2008 to specifically help address the problem of Somali piracy for the first time. The intention was to widen the scope of international legal rules on piracy in order to cope with this growing alarm. The SC filled some gaps in the UNCLOS by expanding their enforcement jurisdiction and by encouraging cooperation among states to enhance their abilities in the fight against piracy, especially regarding every necessary aspect of the alleged pirates' prosecution for taking hostages and their potential imprisonment, including capacity building in both areas. Somali piracy goes on the SC agenda nowadays since the root of the problem (Somalia as a failed state and all the questions it entails) persists unresolved and some jurisdictional loopholes endure, particularly providing an efficient prosecutorial regime. 
Starting from UNSCR 1816/2008, the international community response brought about an unprecedented and spectacular deployment of warships by more than twenty nations to patrol the area. Thus, they have shown a determined effort to undertake the high cost this enforcement jurisdiction entails; but they have not assumed the duties to prosecute the alleged pirates captured, as they are empowered to do by Art. 105 of UNCLOS in the exercise of the universal jurisdiction to prosecute.

As most SC Resolutions have linked the pirates' activities off the Somali coast with the notion of a threat to international peace and security, they have been enacted under Chapter VII of the UN Charter framework, entailing that, according to Art. 25, they are legally mandatory on every state, making it possible to circumvent UNCLOS through Art. 103.

To sum up, there are two interesting facts to point out: the shifting in the sequence of the UNSCRs from emphasising authority to use force to requirements towards a higher law-enforcement cooperation and the search for bases on which to assert jurisdiction over pirates. And on the other hand, in search for a comprehensive international response, the general consensus to embrace the problem of piracy in Somalia, from a multifaceted perspective containing provisions, fosters a wide range of cooperative actions to improve capabilities to repress the piracy phenomenon. The main goal is to find a solution to the problem of what to do about pirates once captured by the warships of cooperating states, i.e., the capacity-building regarding their prosecution and imprisonment as prison facilities, transfer agreements with other regional countries besides Kenya, post-trial agreements of convicted pirates (this concept entails the transfer of a pirate sentenced in one state to be incarcerated in another state) as is the case between Seychelles and TFG, Somaliland and Puntland.

\section{REFERENCES}

Atallah, R. (2011). Pirate Financing: Understanding and Combating a Complex System. Proceedings of Conference on Global Challenge, Regional Responses: Forging a Common Approach to Maritime Piracy, Dubai. (http://counterpiracy.ae/background_papers.html).

Bair, R. S. (2009). Disrupting Somali Piracy via Trust and Influence Operations. MSc Thesis, Monterey, California. (http://www.tdsi.nus.edu.sg).

Baniela, S.I. (2010). Piracy at Sea: Somalia an Area of Great Concern. Journal of Navigation, 63, 191-206.

Bento, L. (2011). Toward an International Law of Piracy Sui Generis: How the Dual Nature of Maritime Piracy Law Enables Piracy to Flourish. Berkeley Journal of International Law, 29, 399-455.

BMP4 (2011). Best Management Practices for Protection against Somalia Based Piracy, 2011 Edition. Witherby, Edinburgh.

Bordas, M. F (2009). "Los intentos de solución" in Crisis somali, piratería e intervención internacional. Instituto Universitario "General Gutiérrez Mellado", Madrid, 67-100.

Cronjé, D. (2010). The Pirates of Somalia: Maritime Bandits or Warlords of the High Seas. MSc Thesis, Stellenbosch University, South Africa. (http://scholar.sun.ac.za/handle/10019·1/4112).

Davis, W. M. (2009). Analysis of the Strategy to Combat Maritime Piracy. MSc Thesis, North Carolina State University. (http://www.dtic.mil/dtic/tr/fulltext/u2/a512384.pdf).

Failed States Index (2011). Foreign Police Magazine (http://www.foreignpolicy.com/failedstates).

Guilfoyle, D. (2010). Counter-piracy law enforcement and human rights. International and Comparative Law Quarterly, 59, 141-169.

Helman, G. and Ratner, S. (1993). Saving Failed States. Foreign Policy, 89, 3-20.

Hutchins, T.E. (2011). Structuring a Sustainable Letters of Marque Regime: How Commissioning Privateers Can Defeat the Somali Pirates. California Law Review, 88, 819-884. 
ICC-IMB (2006-2010). Piracy and Armed Robbery Against Ships Annual Reports. (http://www.iccccs.org).

IMO (2011a). MSC.1/Circ.1405/Rev.1, 2011. Revised Interim Guidance to Shipowners, Ship Operators, and Shipmasters on the Use of Privately Contracted Armed Security Personnel on Board Ships in the High Risk Area. (http://www.igpandi.org/downloadables/piracy/imo_circulars/).

IMO (2011b). MSC.1/Circ.1406/Rev.1, 2011. Revised Interim Recommendations for Flag States Regarding the Use of Privately Contracted Armed Security Personnel On Board Ships in the High Risk Area. (http:// www.igpandi.org/downloadables/piracy/imo_circulars/).

IMO (2011c). MSC.1/Circ.1408, 2011. Interim Recommendations for Port and Coastal States Regarding the Use of Privately Contracted Armed Security Personnel On Board Ships in the High Risk Area. (http:// www.igpandi.org/downloadables/piracy/imo_circulars/).

Isanga, J. M. (2010). Countering Persistent Contemporary Sea Piracy: Expanding Jurisdictional Regimes. American University Law Review, 59, 1267-1319.

Kontorovich, E. (2010). A Guantanamo on the Sea: The Difficulty of Prosecuting Pirates and Terrorist. California Law Review, 98, 243-276.

Kontorovich, E. (2011). Equipment Articles: An International Evidence Rule for Piracy. Conference on Global Challenge, Regional Responses. Forging a Common Approach to Maritime Piracy, 100-103, Dubai. (http://counterpiracy.ae/background_papers.html).

Kraska, J. (2009). Fresh Thinking For an Old Problem. Workshop on Countering Maritime Piracy. Naval War College Review, 62, 141-154. (http://www.usnwc.edu).

Kraska, J. and Wilson, B. (2008). Fighting Pirates: the Pen and the Sword. World Policy Journal 25, 41-52.

Kraska, J. and Wilson, B. (2009). Piracy Repression, Partnering and the Law. Journal of Maritime Law and Commerce, 40, 43-58.

Leeson, P. T. (2007). Better off stateless. Somalia Before and After Government Collapse. Journal of Comparative Economics, 35, 689-710.

McNeill, J. and Schaefer, B. (2009). Options for Combating Piracy in Somalia. The Heritage Foundation. (http://s3.amazonaws.com/thf_media/2009/pdf/wm2397.pdf).

Middleton, R. (2011). Trends in Piracy: A Global Problem with Somalia at the Core. Global Challenge, Regional Responses. Forging a Common Approach to Maritime Piracy, 21-24, Dubai. (http:/l counterpiracy.ae/background_papers.html).

Møller, B. (2009). The Somali Conflict. The Role of External Actors. Danish Institute for International Studies, Copenhagen.

Murphy, M. (2008). Piracy and the Exploitation of Sanctuary. Armed Groups: Studies in National Security, Counterterrorism, and Counterinsurgency. Norwitz, Newport, 161-171.

Murphy, M. (2009). Somali Piracy: Not Just a Naval Problem. The Center for Strategic and Budgetary Assessments-CSBA. (http://www.csbaonline.org).

Murphy, M. (2011). Future Scenarios and Future Threats: What Happens if Piracy is not Controlled, and How Might Manifestations Change? Proceedings of Conference on Global Challenge, Regional Responses: Forging a Common Approach to Maritime Piracy, 36-40, Dubai. (http://counterpiracy.ae/ background_papers.html).

Ong-Webb, G. G. (2007). Piracy in Maritime Asia: Current Trends. Violence at Sea: Piracy in the Age of Global Terrorism, Peter Lehr, New York, 37-93.

Powell, B., Ford, R. and Nowrasteh, A. (2008). Somalia After State Collapse: Chaos or Improvement? Journal of Economic Behavior \& Organization, 67, 657-670.

Richard, T. T. (2010). Reconsidering the Letter of Marque: Utilizing Private Security Providers Against Piracy. Public Contract Law Journal, 39, 411-464.

Riggs, S. (2009). Piracy in the Horn of Africa: A comparative study with Southeast Asia. Master's thesis, Monterey, California. (www.dtic.mil/dtic/tr/fulltext/u2/a514377.pdf).

Roach, J. A. (2010). Suppressing Somali Piracy - Next Steps. American Society of International Law (Insight reports), Volume 14, Issue 39.

Schaefer, B. D. (2009). Piracy: A Symptom of Somalia's Deeper Problems. The Heritage Foundation. (http://www.heritage.org/Research/Africa/upload/wm_2398-pdf.pdf).

Schermerhorn, L. (2011). The Man from Minnesota: A Model for Local Economic Development? Proceedings of Conference on Global Challenge, Regional Responses: Forging a Common Approach to Maritime Piracy, 56-59, Dubai. (http://counterpiracy.ae/background_papers.html).

Schwartz, A. (2010). Corsairs in the Crosshairs: A Strategic Plan to Eliminate Modern Day Piracy. New York University Journal of Law \& Liberty, 5, 500-530. 
Sepúlveda, I. (2009). Estados fallidos: la quiebra del estado nacional y la desestabilización de la seguridad nacional. Crisis somali, piratería e intervención internacional, 15-33. Instituto Universitario "General Gutiérrez Mellado", Madrid.

Silva, M. (2010). Somalia: State Failure, Piracy, and the Challenge to International Law. Virginia Journal of International Law, 50, 553-578.

Thürer, D. (1999). The "Failed State" and International Law. International Committee of the Red Cross, 836, 731-761.

Wombwell, J. A. (2010). The Long War Against Piracy: Historical Trends. Combat Studies Institute Press occasional paper; 32, Kansas. (http://www.cgsc.edu/carl/download/csipubs/wombwell_32.pdf). 